\title{
A REDE HIDROGRÁFICA NO MAPA DE PORTUGAL DE FERNANDO ÁLVARO SECO (1560)
}

\author{
SuZANNE Daveau ${ }^{1}$
}

\begin{abstract}
Resumo - A análise cartográfica da rede hidrográfica, no mapa de Portugal de Fernando Álvaro Seco, mostra por um lado a sua boa qualidade de conjunto e permite, por outro lado, procurar as causas dos erros de traçado e orientação, bem como das omissões que se detectam. Confrontou-se, para isso, o traçado dos rios com descrições de itinerários da mesma época e analisou-se também a repartição das pontes e da hidronímia. Reconheceu-se uma forte correlação espacial entre a qualidade da representação e a densidade e frequência dos itinerários viários, e a influência das preocupações militares relativas à raia oriental do Reino. A correlação com as características do relevo e clima regional é importante, mas menos directa. O cartógrafo que construiu o mapa procedeu a um complexo trabalho de compilação e harmonização de documentos de origens diversas, cuja recolha é provavelmente bem anterior à data da oferta do mapa em Roma, em 1560.
\end{abstract}

Palavras-chave: História da Cartografia, Portugal, rede hidrográfica.

Résumé - Le RÉSEAU hydrographique de la carte du Portugal de Fernando ÁLVARO SECo (1560). L'analyse cartographique confirme la bonne qualité d'ensemble du réseau et permet de rechercher les causes des erreurs de tracé et d'orientation ainsi que des omissions qui ont été détectées. On a confronté le dessin des cours d'eau avec des descriptions d'itinéraires contemporaines et on a analysé la répartition des ponts et de l'hydronimie. La qualité de la représentation est en forte corrélation spatiale avec la densité et la fréquentation des chemins et paraît liée aussi aux préoccupations militaires relatives à la frontière orientale du royaume. Les liens avec les caractères régionaux du relief et du climat sont importants mais indirects. Le cartographe qui a construit la carte semble avoir réalisé un complexe travail de compilation et d'harmonisation, à partir de documents d'origines diverses, réunis sans doute bien avant la date où cette carte a servi à Rome de présent diplomatique, en 1560 .

Mots-clés: Histoire de la cartographie, Portugal, réseau hydrographique.

Abstract - The hydrographic NeTWORK IN THE MAP OF PoRtugal By Fernando ÁlVARO SECO (1560). A cartographic examination of the hydrographic network demonstrates, on one hand, its high quality in general and allows us, on the other hand, to seek reasons for the mistakes in its drawing and orienting, as well as the omissions made. To this effect, the plotting of the rivers was compared with itineraries descriptions of that same period. An examination was also made of the distribution of bridges and hydronymy. A solid spatial correlation was found to exist

1 Investigadora do Centro de Estudos Geográficos, Universidade de Lisboa. (Endereço do CEG no início do volume). E-mail: s.daveau@mail.telepac.pt. 


\begin{abstract}
between the quality of the plotting and the density and frequency of the various itineraries, along with the influence of military concerns for the Eastern boundary of the Portuguese kingdom. The correlation with the regional properties of relief and climate is important but less direct. The map-maker undertook complex work of compilation and harmonisation of documents of several origins, probably dating much further back than to when the map was offered in Rome in 1560.
\end{abstract}

Key words: History of Cartography, Portugal, hydrographic network

\title{
INTRODUÇÃO
}

O mapa de Portugal, que serviu de oferta diplomática em Roma, em Maio de 1560, como se mostrará no fim deste estudo, é atribuído pela dedicatória a Fernando Álvaro Seco (Vernandi Alvari Secco) e é geralmente considerado a primeira representação cartográfica do conjunto do País. Com uma escala de cerca de 1:1200000, é de tipo corográfico. Uma das suas características mais notáveis é a abundância e boa qualidade do traçado da rede hidrográfica. Esta cobre todo o território nacional, com uma densidade bastante regular (fig. 1) e comparável à dos numerosos lugares habitados que aparecem localizados e nomeados no mapa.

No entanto, o levantamento de uma série de cursos de água, hierarquizados em redes às vezes extensas e complexas, terá posto, a quem recolheu no terreno os elementos destinados a constituir o mapa e a quem os interpretou depois, problemas técnicos bem mais difíceis que a simples colocação relativa dos pontos habitados, situados ao longo de itinerários conhecidos, cruzando-se em geral nas sedes administrativas principais. Não bastava, para representar a rede hidrográfica, saber que se atravessava tal ou tal rio antes ou depois de atingir determinada povoação; era preciso ainda conhecer a origem da linha da água, o sentido do escoamento, e para que lugar corria, com a dificuldade suplementar da possível mudança dos nomes, ao longo dum mesmo rio.

Se a primeira impressão colhida, ao observar o mapa, é da forte densidade da informação hidrográfica conseguida pelo autor em todo o território nacional, a apreciação da qualidade desta informação torna-se menos fácil. A distorção desigual, que as várias regiões portuguesas sofreram neste mapa, dificulta, em muitos casos, a identificação à primeira vista dos rios representados, tanto mais que muitos deles ficaram anónimos ou têm designações diferentes das que se encontram nos mapas e repertórios recentes ou actuais (BAPTISTA, 1874, I: 25-174; Índice..., 1981).

\section{TÉCNICAS DE ESTUDO}

Para realizar um estudo equilibrado do conjunto da rede, foi portanto necessário transpor os rios presentes no mapa de Fernando Álvaro Seco para um fundo de mapa moderno. Utilizou-se para isso a Carta de Portugal, na escala 
de 1:500 000, do Instituto Geográfico e Cadastral, na edição de 1974, completando-se a informação, onde foi preciso, com a consulta das 6 folhas da carta 1:250 000 do Serviço Cartográfico do Exército (1965-68), por ser a edição que tem a representação hidrográfica mais rigorosa, e dos preciosos dados reunidos no estudo de «Toponímia territorial» de Joaquim da Silveira, incluído em «O mais antigo mapa de Portugal» (FERREIRA et al., 1956-57); e utilizaram-se ainda, pontualmente, outras fontes de informação. Tomando em conta tanto o desenho dos rios como a localização relativa das povoações próximas, foi possível elaborar a figura 1, que não apenas indica os rios ou segmentos de rios representados no mapa de Portugal de 1560, como assinala também os principais erros ou omissões que afectam esta representação.

Foram comparadas as três primeiras edições que conheceu o mapa de Fernando Álvaro Seco: a edição dita de Roma, que ostenta na dedicatória a data de 1561 (PMC, est. 197), a de Antuérpia, de 1565 e com dedicatória datada de 1560 (PMC, est. 198), e a que foi incluída em 1570 na primeira edição do Theatrum Orbis Terrarum de Abraham Ortelius e reproduzida, em 1956-57, no estudo acima citado. Verificou-se rapidamente que o mapa de 1570 é praticamente idêntico ao que tem a data de 1561, no que diz respeito ao desenho da rede hidrográfica: o mesmo traçado e os mesmos nomes, ainda que falte parte substancial das pontes indicadas no mais antigo. Aliás, as escalas são muito próximas (respectivamente cerca de 1:1200000 e 1:1250 000), o que terá facilitado a cópia.

A edição de Antuérpia, que se considera geralmente baseada na de Roma, apresenta no entanto, relativamente a ela, várias simplificações e lapsos. Em 1565 não se reproduziram as numerosas pontes do mapa de 1561 (apenas uma, a de Coimbra) e alguns nomes de rios desapareceram ou encontram-se deslocados. Desapareceu o nome de Tamaga (Tâmega), aliás colocado pouco acertadamente, em 1561, no rio da Ovelha, pequeno afluente paralelo ao baixo Tâmega. Surgiu, em compensação, o nome de Cabado (Cávado), a completar o de Mourilhe, o único presente no mapa de 1561, no troço superior do rio (fig. 1 e 5). Também o nome de R. Odivelas aparece apenas no mapa mais recente (fig. 2). Estes dois últimos factos parecem indicar que não se utilizou como modelo, em 1565, o mapa editado em Roma mas qualquer exemplar parecido, talvez a própria minuta ou original daquele.

O nome Rio da Palma, que designa ainda hoje um pequeno afluente do baixo Sado, encontra-se ligeiramente deslocado no mapa de 1565 e parece assim ser o nome do rio principal (fig. 2). Notam-se ainda, entre as duas edições, pequenas diferenças no traçado de certos rios. Veja-se, por exemplo, na figura 2, o desenho do rio que corre de Évora Monte para Pavia: no mapa de 1565, faltam-lhe alguns subafluentes e o nome R. Almadafres, ligeiramente deslocado, passa a designar o actual Tera. Além disso, as inflexões de pormenor dos cursos são sensivelmente diferentes

Mas é preciso tomar em conta a forte diferença de escala entre os dois mapas (1:1 $200000 \mathrm{em} \mathrm{1561,} \mathrm{1:750000} \mathrm{em} \mathrm{1565).} \mathrm{É} \mathrm{provável} \mathrm{que} \mathrm{a} \mathrm{informação}$ 


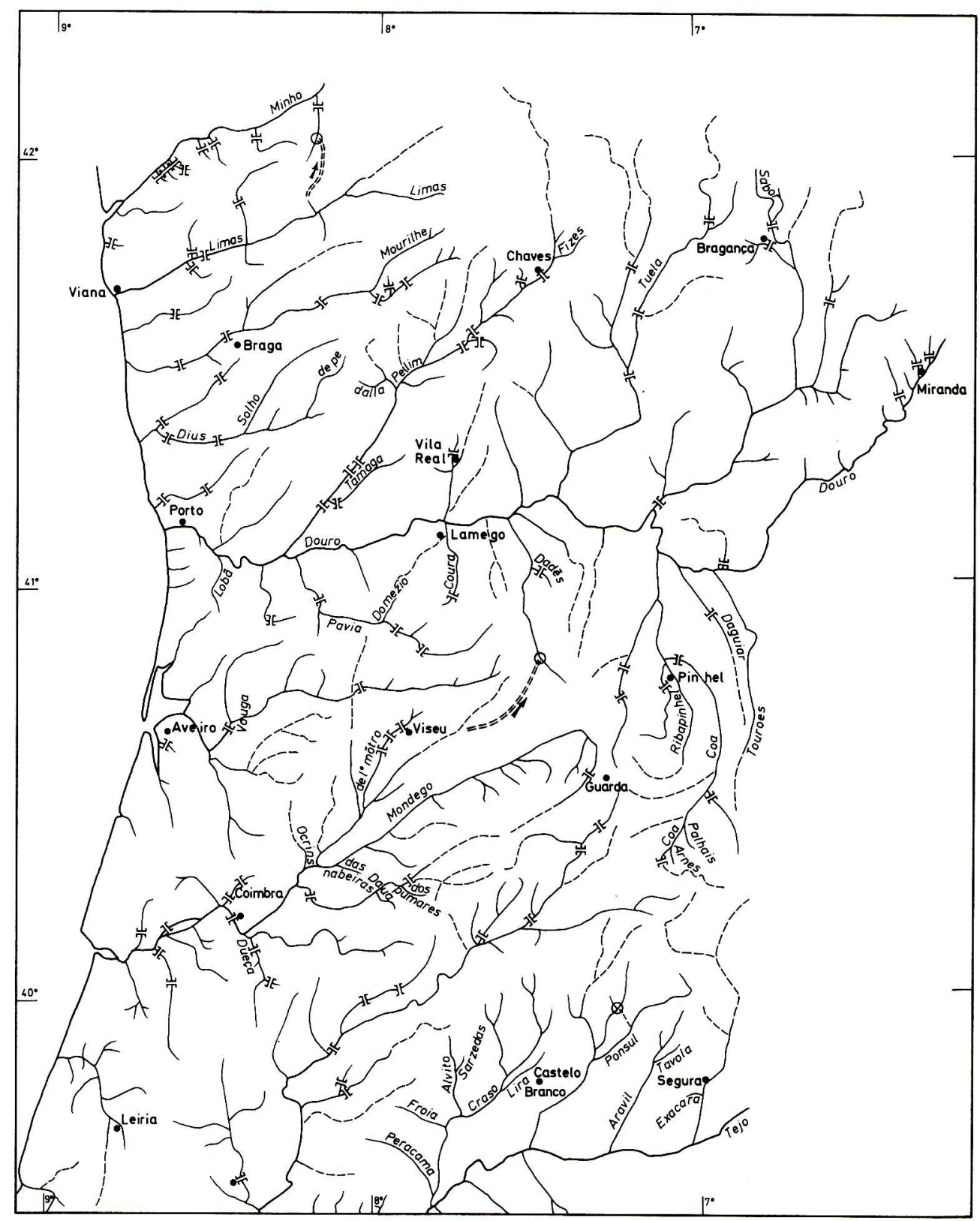

Fig.1 - A rede hidrográfica do mapa de Portugal de Fernando Álvaro Seco (1561), implantada num fundo de mapa moderno (Carta de Portugal, 1:500 000, 1974). Mostram-se os segmentos de rio presentes no mapa, com os nomes que lhes são atribuídos e as pontes que os atravessam, os principais segmentos ausentes e, ainda, os erros que foram detectados (segmentos de rio imaginados ou invertidos e confluências erradas). 


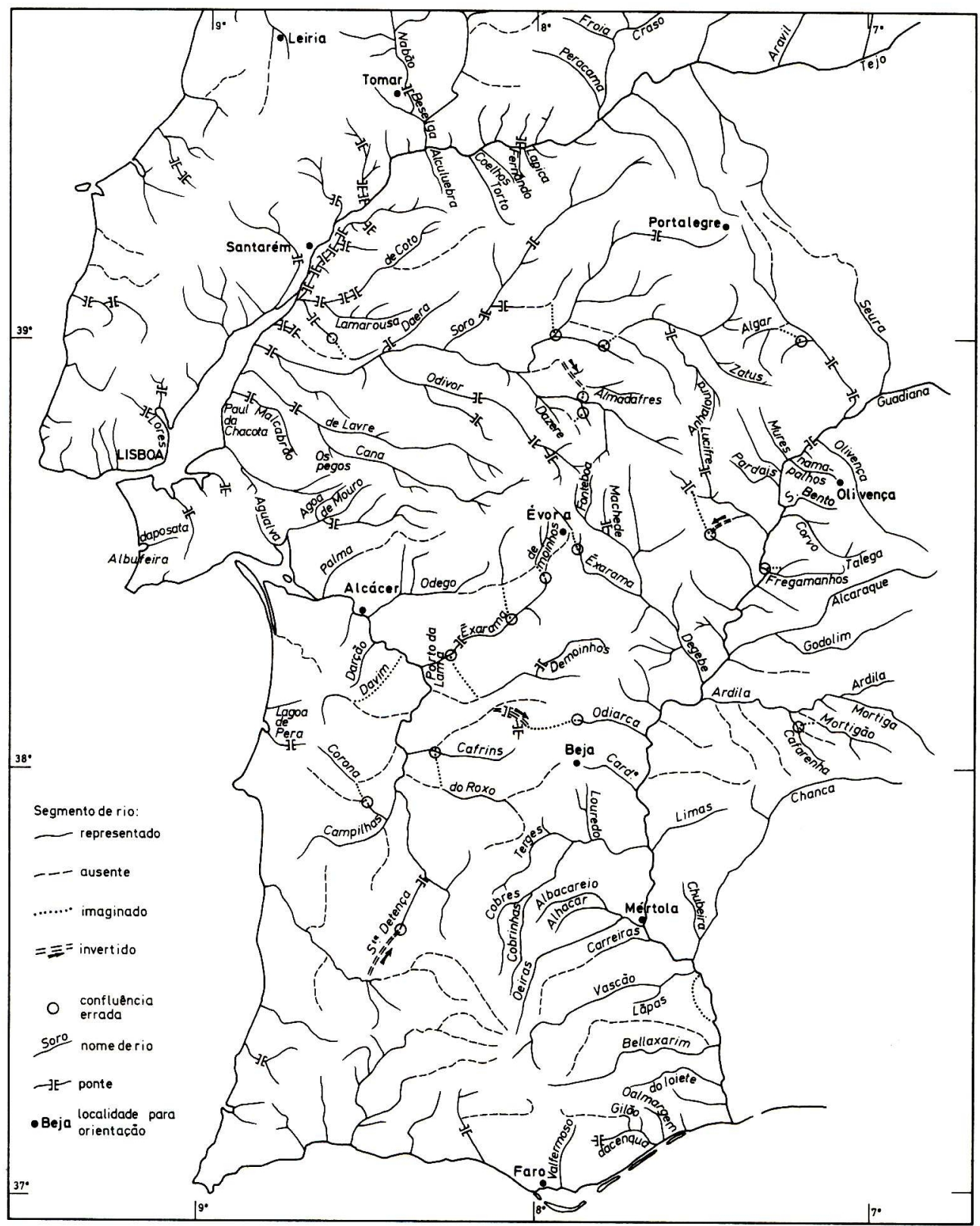

Fig.1 - The hydrographic network in the Fernando Álvaro Seco map of Portugal (1561) placed over a modern map (Carta de Portugal, 1:500,000,1974). The segments of the river on the map are shown with their names and the bridges that cross them, the main missing segments and also the errors detected (either imagined river segments or drawn the wrong way round, and mistaken confluences) 


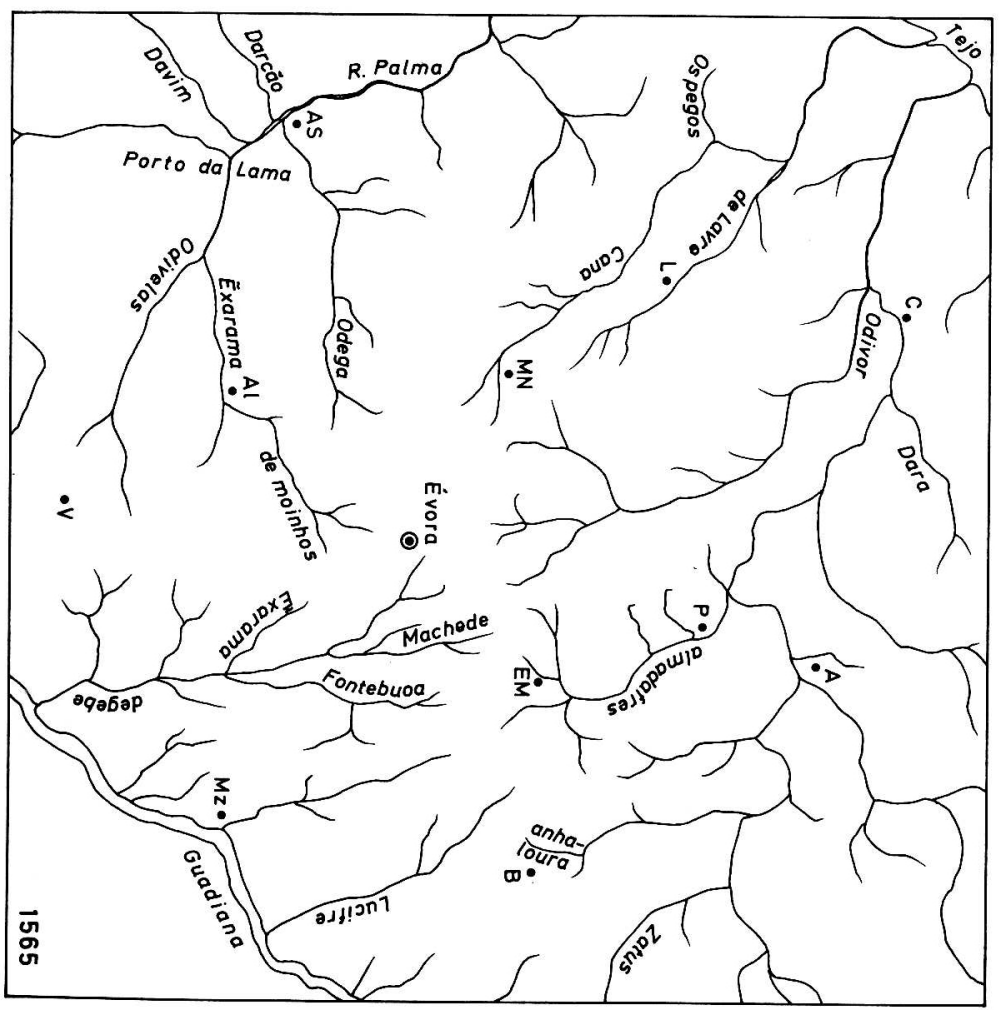

$\longmapsto 1 / 2$ grau de meridiano

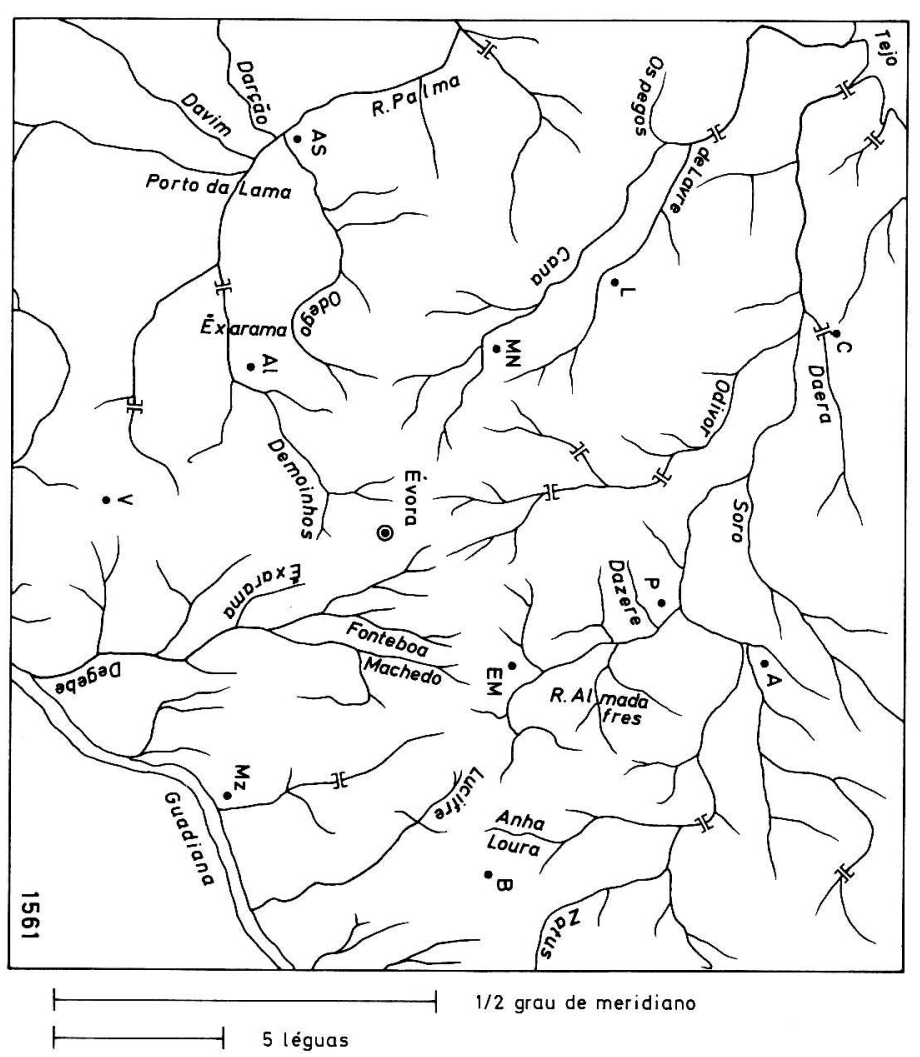

a

Fig.. 2 - A rede hidrográfica do interflúvio Tejo-Guadiana nas versōes de Roma (1561) e de Antuérpia (1565) do mapa de Portugal de Fernando Álvaro Seco. Ver o significado das abreviaturas na legenda da fig. 4 . Fig. 2 - The interfluve Tagus-Guadiana hydrographic network in the Rome version (1561) and Antwerp version (1565) of the Fernando Álvaro Seco map. See key to abbre-
viations in the Figure 4 caption. 

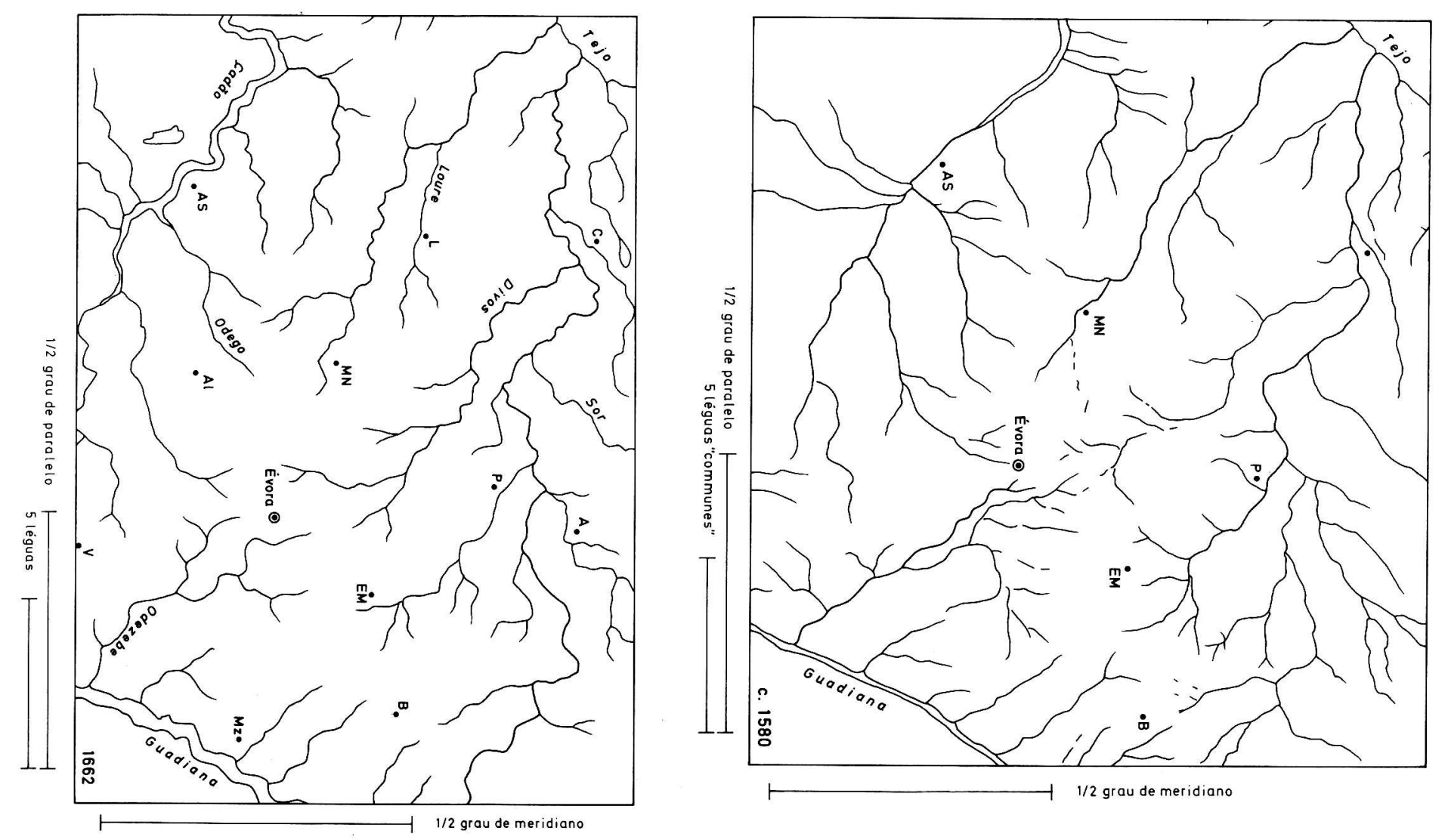

Fig. 3 - A rede hidrográfica do interflúvio Tejo-Guadiana no mapa do Escorial (cerca de 1580) e no mapa de Pedro Teixeira Albernaz (1662). Ver o significado das abreviaturas na legenda da fig. 4

Fig. 3 - The interfluve Tagus-Guadiana hydrographic network in the Escorial map (circa 1580) and in the Pedro Teixeira Albernaz map (1662). See key to abbreviations in the Figure 4 caption. 
tenha sido transposta com a ajuda de uma quadrícula, não tendo assim o desenhador nem a pretensão nem a possibilidade de realizar traçados de grande minúcia, mas apenas a de restituir com boa aproximação a disposição relativa dos diversos ramos da rede. As diferenças de pormenor no traçado dos rios deixam, neste provável contexto técnico, de ter muito significado, sobretudo quando comparadas com as modificações bem mais acentuadas que caracterizam os dois mapas posteriores de Portugal actualmente conhecidos (fig. 3), o mapa dito do Escorial, considerado de cerca de 1580 (PMC, est. 199), e o de Pedro Teixeira Albernaz, impresso em 1662 (PMC, est. 519). E, mais ainda, quando se faz a comparação com o desenho da rede hidrográfica nos mapas modernos, estabelecidos com recurso a técnicas de levantamento e generalização bem diferentes, como a Carta de Portugal de 1974, 1:500 000, que foi utilizada como fundo para a transposição (fig. 4).

Por isso pareceu suficiente, no presente estudo e numa primeira aproximação, considerar apenas o traçado da rede hidrográfica no primeiro dos mapas conhecidos, o que tem a data de 1561, tanto mais que este traçado foi exactamente retomado no mapa de 1570 e conheceu, a partir desta data, uma ampla difusão internacional.

\section{CARACTERÍSTICAS DE CONJUNTO}

A leitura do traçado da rede hidrográfica do mapa de 1561, depois de transposto para um fundo moderno (fig. 1), confirma a densidade impressionante da informação já então reunida e a sua espantosa exactidão de conjunto. Confirma também uma notável homogeneidade inter-regional da quantidade e qualidade da informação, sugerindo que a preparação do mapa foi concebida a nível nacional e não resultou apenas de pura compilação de informações já existentes, que teriam sido recolhidas independentemente a nível local ou regional.

No entanto, esta homogeneidade de conjunto está longe de ser perfeita. Sem descer ainda à consideração dos pormenores locais, que serão exemplificados a seguir, verifica-se na figura 1 que a densidade da rede hidrográfica é um pouco maior a sul do Tejo do que no Norte do País. Em compensação, aparecem mais erros de traçado nas planícies do Sul do que no meio das colinas e serras situadas ao norte do grande rio, provavelmente porque era mais difícil, para quem recolhia a documentação, apreciar o percurso dos rios quando o vigor do relevo circundante não o sublinhava claramente na paisagem. Também parece que os rios temporários do Sul tinham menos probabilidade de serem indicados pelos informadores locais, por dificultarem muito menos a circulação dos viajantes que os rios permanentes e caudalosos do Norte.

Numa leitura de pormenor, à escala dos conjuntos regionais ou sub-regionais, observa-se na figura 1, a sul do Tejo, um forte contraste entre o Alentejo ocidental, onde abundam os erros de traçado, e a parte oriental, onde a representação gráfica dos afluentes do Guadiana, não só é notavelmente densa e 


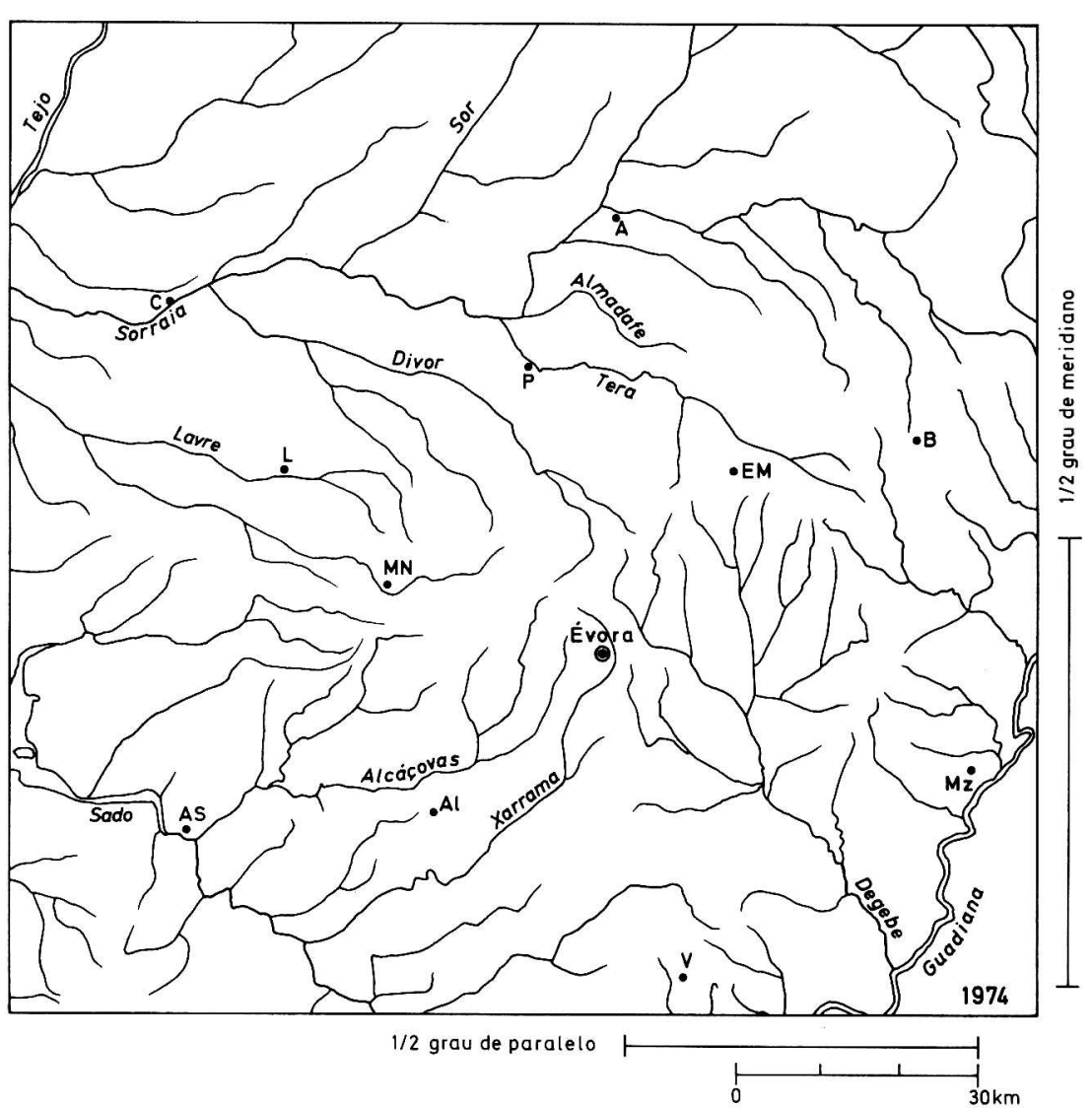

Fig. 4 - A rede hidrográfica do interflúvio Tejo-Guadiana na Carta de Portugal, 1:500 000 (1974). Abreviaturas:

A - Avis, Al - Alcáçovas, AS - Alcácer do Sal, B - Borba, C - Coruche, EM - Évora Monte, $\mathrm{L}$ - Lavre, MN - Montemor-o-Novo, Mz - Monsaraz, P - Pavia.

Fig. 4 - The interfluve Tagus-Guadiana hydrographic network in the Carta de Portugal, 1:500,000 (1974). [Abbreviations: see above]

exacta, como é completada por uma abundante toponímia, que chega a nomear cursos de água muito pequenos.

Além dos erros de traçado propriamente ditos (falsas confluências e cursos invertidos), destacam-se também no mapa alguns espaços onde foi omitida a representação de rios bastante importantes. Em muitos casos, estes espaços correspondem a áreas montanhosas que constituem as divisórias de água principais. Citam-se em particular as divisórias entre Douro e Tejo (Serra da Malcata e rebordo do planalto de Sabugal), entre Zêzere e Mondego (Serra da Estrela), entre Mondego e Vouga (Serra do Caramulo).

Mas, noutros casos, os espaços desprezados são de relevo muito semelhante aos que os enquadram e que mereceram uma representação bem mais porme- 
norizada. Comparem-se, por exemplo, as partes ocidental e oriental da Serra do Caldeirão, a região entre Serpa e Moura com a situada imediatamente a leste no Além-Guadiana, ou ainda a região entre Penedono, Meda e Trancoso, no contexto da Beira Alta. Os espaços «esquecidos» não serão sobretudo, em muitos casos, os menos habitados, os menos sulcados por caminhos frequentados? Se não se pode pôr de lado por completo a hipótese de lapsos do desenhador, parece existir uma correlação bastante boa entre a frequência habitual dos caminhos e a densidade da informação hidrográfica incorporada no mapa.

Antes de tentar elaborar hipóteses consistentes sobre as técnicas de levantamento do mapa de Fernando Álvaro Seco e sobre o ambiente socio-económico que rodeou o empreendimento, convém examinar com mais atenção alguns casos locais de erros ou, pelo contrário, de notável acerto, no desenho que oferece da rede hidrográfica de Portugal.

\section{A REDE HIDROGRÁFICA NO SUL DO PAÍS}

A parte do País que apresenta mais erros no desenho da rede hidrográfica é, sem contestação, a bacia do Sado. Vários dos pequenos afluentes deste rio são cruzados por pontes, que parecem indicar a passagem de caminhos terrestres bastante frequentados. Mas quase todos os afluentes seguem traçados inexactos, confluindo entre si como que ao sabor da fantasia do cartógrafo, que terá intercalado segmentos imaginários de ligação entre os que encontrou indicados nos itinerários consultados. Dois casos são particularmente curiosos. Primeiro, o de dois pequenos ramos confluentes e providos de pontes, situados a NE de Ferreira do Alentejo, que foram submetidos pelo cartógrafo a uma inversão de escoamento, para ficarem ligados ao Odiarça, afluente do Guadiana (fig. 1 e 2), quando são, na realidade, subafluentes do Sado (fig. 4). Depois, a enigmática Ribeira de Sta. Detença, resultante da inversão do curso de um afluente do Rio Mira, a SW de Garvão. Este ramo irá ter o duvidoso privilégio de representar, até ao século XVIII, em todos os mapas de Portugal, nacionais e estrangeiros, um imaginário eixo superior do Sado.

Em termos gerais, o mau conhecimento hidrográfico da bacia do Sado resulta muito provavelmente do fraco povoamento desta parte do País no começo do século XVI (veja-se o mapa II, da distribuição da população em 1527-32, em GALEGO, DAVEAU, 1986). A pouca circulação terrestre fazia-se então principalmente ao longo de um percurso sublitoral, ligando Lagos a Alcácer do Sal, e por caminhos transversais que levavam das cidades ou vilas interiores até aos términos da navegação fluvio-marítima (Odemira no Rio Mira e o Porto da Lama no Rio Sado, indicado no mapa na confluência do Xarrama).

Mas é um factor de tipo bem diferente, de índole natural, que tem de ser considerado para explicar os estranhos erros que marcam os arredores de Évora, lugar muito frequentado e que, a priori, devia ser bem conhecido dos 
funcionários régios encarregados de juntar a documentação para o mapa: a excepcional complexidade e difícil leitura na paisagem do traçado da rede hidrográfica, num lugar de planície onde se manifesta, no entanto, uma divergência geral da drenagem (comparem-se as figuras 2 e 4). Com efeito, o ramo superior do Rio Xarrama nasce a NE de Évora e circunda primeiro a cidade a leste, a fraca distância, mas num vale tão largamente aberto que é difícil discerni-lo na paisagem muito plana dominada pela cidade. O rio vira a seguir para SW, em direcção ao Sado. Ora, o cartógrafo tomou a decisão de desdobrar este estranho curso de água em dois rios, que chamou igualmente Enxarama, fazendo do primeiro um afluente do Sado e do outro um afluente do Guadiana.

Em compensação, a bacia portuguesa do Guadiana tem uma representação notavelmente exacta e abundante em toponímia, mesmo em espaços escassamente povoados como o Campo de Ourique. São muito poucos os erros: uma troca de nomes entre o rio Beliche e o Odeleite, a falta já assinalada de afluentes da margem esquerda na região de Mourão e a estranha invenção de uma ilha, à volta de Alcoutim. A fonte deste último erro só pode ter sido a confusão, pelo cartógrafo, entre um traço indicando um caminho, que tomou por um braço do rio, num esboço preliminar que teria consultado. O mais estranho, exemplo significativo da durável e perniciosa conservação dos erros em Cartografia, é que este traçado imaginário, cuja incorrecção era tão fácil de detectar e que não pode ter escapado aos numerosos viajantes que seguiam por terra entre a foz do Guadiana e Beja ou Serpa, perdurou nos mapas posteriores, como o do Escorial (cerca de 1580) ou o mapa dito da Gulbenkian (cerca de 1640, PCM, est. VI da adenda, 1987). No entanto o erro foi corrigido no mapa de Pedro Teixeira Albernaz, em 1662, ao contrário do segmento da Sta. Detença, muito mais longamente conservado, numa região pouco percorrida.

O facto de o Guadiana ser rio fronteiriço explica provavelmente o levantamento pormenorizado de que foi alvo desde cedo. Conhecemos o itinerário descritivo que Duarte de Armas anexou em 1509 ao seu Livro das Fortalezas (AlmEIDA, 1943; ARMAS, 1997). Sobreviveram igualmente, desta região fronteiriça, mapas mais tardios, também muito ricos em dados hidrográficos, como a Carta da região fronteiriça do Alentejo, de cerca de 1646 (BN CC 254) ou a Carta gravada do Alentejo de Bartolomeu de Sousa, 1665 (Tesouros..., 1997: 60); mas estes mapas carecem de estudo.

\section{A REDE HIDROGRÁFICA NO NORTE DO PAÍS}

Como já foi dito, os erros de traçado são muito menos numerosos a norte do Tejo do que a sul. Apenas ocorre com alguma frequência, no Centro e no Norte de Portugal, a não representação dos rios das áreas serranas de relevo elevado e recortado, que os viajantes atravessavam raramente, por serem contornados pelos principais caminhos inter-regionais. Nota-se também a 
existência de tipos diferentes na informação recolhida. Nalgumas bacias os nomes de rios multiplicam-se, noutras rareiam; em certas bacias as pontes são numerosas, noutras faltam por completo. Comparem-se, por exemplo (fig. 1), a bacia do Zêzere, absolutamente desprovida de nomes, mas rica em pontes, e o conjunto dos afluentes da margem direita do Tejo, na Beira Baixa, que são abundantemente nomeados, mas onde não aparece ponte alguma.

Detectam-se apenas, a norte do Tejo, dois erros flagrantes, por incorporarem inversões de drenagem (fig. 1). Na Beira Alta o curso superior do Rio Dão (não nomeado) é considerado como um afluente do Távora (também não nomeado e enquadrado por espaços onde os afluentes do Douro que lhe são paralelos - os rios Teja, Torto e Tedo -, nem sequer são desenhados). Trata-se de uma área que devia ficar então bastante isolada, entre os dois grandes eixos de circulação norte-sul, passando, o mais ocidental, por Viseu, Castro Daire e Lamego, e ligando, o outro, a região da Guarda ao Douro, pelo grande plano regularmente inclinado de Pinhel, onde se nota uma densidade elevada de pontes. A qualidade do conhecimento e do apetrechamento viário da bacia do Côa deve resultar sobretudo da sua posição fronteiriça, como se notou já relativamente ao Guadiana. Repare-se ainda na estranha densidade de pequenos afluentes não nomeados, que acidentam a margem portuguesa da garganta internacional do Douro; ela parece resultar dum levantamento especial, que teria sido dedicado aos arredores da praça-forte de Miranda.

Outro caso curioso, e que merece uma análise mais aprofundada, é o da rede hidrográfica correspondente à Serra da Peneda (fig. 5), região também fronteiriça, mas agreste e mal controlada pelo poder central. A análise desta representação é favorecida pela conservação do testemunho escrito de diversos viajantes, que circularam então na região. Vale a pena esmiuçar um pouco estes documentos (fig. 6). Permitem, por um lado, apreciar os tipos de dados recolhidos então pelos viajantes mais atentos, especificamente encarregados de tomar nota das características dos itinerários e, por outro lado, confirmam que certos espaços, considerados demasiado difíceis ou perigosos, eram sistematicamente evitados.

Durante o Verão de 1509, Duarte de Armas, encarregado de «pintar» as fortalezas raianas, foi de Montalegre até Portelo (Sendim) por um bom caminho de «uma légua boa», tendo atravessado um rio provido de pontes (o Cávado). Daí, foi ter à fortaleza da Piconha, perto de Rendim, por um muito mau caminho de 2 léguas, tendo atravessado algumas ribeiras pequenas. Para atingir Castro Laboreiro teve, a seguir, de franquear "5 léguas de serras e muitas ribeiras, entre as quais a maior há nome Lima»; o que mostra que atravessou em linha directa as terras galegas, facto confirmado pela não descrição do castelo do Lindoso (fig. 5 e 6). De Castro Laboreiro desceu a Melgaço, por um caminho de «2 léguas mui fragosas, todo de serra, ribeiras nem uma». A sucinta descrição que deixou do seu itinerário é de grande interesse; ainda que muito simples, indica sistematicamente a distância em léguas, a qualidade do caminho e os rios atravessados, providos ou não de pontes. 
Em fins de Agosto de 1527, Álvaro Vaz, encarregado de realizar o Numeramento dos moradores de Entre Douro e Minho (DIAS, 1999), começou pelo concelho da Nobrega (Ponte da Barca), passou a seguir para o do Lindoso, cujo castelo se encontrava ermo, continuou pelo concelho do Soajo, pelo do Valdevez e pelo de Coura, para passar depois ao de Castro Laboreiro, sem indicar o caminho que utilizou, mas seguindo muito provavelmente o vale superior do Rio Mouro (fig. 6). Notou, em Castro Laboreiro, que «vivem no Verão neste concelho cem moradores porque no Inverno se vão viver fora por ser terra fria», acrescentando que o castelo estava ermo e «povoado de gralhas». Desceu depois de Castro Laboreiro para Melgaço, seguindo então o vale do Minho até Caminha. Contornou portanto cuidadosamente a parte mais alta da Serra da Peneda, alongando assim bastante o seu caminho, a despeito da viagem ter decorrido antes do fim do Verão.

Em Janeiro de 1533, encontrando-se no mosteiro de Ermelo e querendo ir ao de Fiães, a comitiva do Abade de Cister, do qual Claude de Bronseval era escrivão (BRONSEVAL, 1970), foi informada de que existia um caminho directo, de apenas 4 léguas, que cruzava a serra da Peneda, mas que era muito mau e pouco seguro («montes horrendissimos, patriamque frigidissiman et desertissiman, vianque male securam propter limites Galeciae et Portugalliae ibidem concurrentes»). O monge lembra aliás, várias vezes, no seu relatório, a insegurança desta região fronteiriça, onde os habitantes não saíam de casa sem estarem armados. A comitiva do Abade decide, portanto, dar a volta à serra, passando por Villadarcha (Arcos de Valdevez) e o vale do Minho (fig. 6).

A seguir, para ir de Fiães a Pitões das Júnias, atravessam em dois dias a parte galega do vale do Rio Lima, como já tinha feito Duarte de Armas. É possível reconstituir quase perfeitamente este itinerário, introduzindo alguns retoques à proposta inicial de D. Maur Cocheril, em 1970. No primeiro dia (26 de Janeiro de 1533) os viajantes vão dormir a Vilarino, depois de uma subida íngreme, que durou uma hora, e de 2 léguas grandes através de uma vasta região estéril, fria e chuvosa, correspondente ao planalto desabrigado que se estende, a leste de Castro Laboreiro, a cerca de $1300 \mathrm{~m}$ de altitude. Antes de atingir Vilarino, tiveram de atravessar um rio apertado entre montanhas (provavelmente o Rio Fragoso). No dia seguinte, estando a terra coberta de neve e com a ajuda dum guia local, atravessam o Lima, numa estreita ponte de madeira onde são obrigados a andar em fileira, puxando cada um o seu cavalo. Voltam a subir, andam perdidos durante meia hora, descem ao vale do Rio Salas, que têm de passar a vau porque a ponte não estava em condições, atingem Requias e sobem à Portela de Pitões, passagem tornada perigosa pela sua altitude elevada $(1200 \mathrm{~m})$, o chão paludoso e a abundância de neve e granizo. Entre grandes fragas, descem então a Pitões e vão ainda, no mesmo dia, visitar o mosteiro próximo de Júnias.

Já no dia seguinte, partem de Pitões «em direcção a Lamego». Este enunciado basta para mostrar que era então possível planear deslocações a longa distância, mesmo através das serras agrestes do Norte. Em toda a parte, resi- 


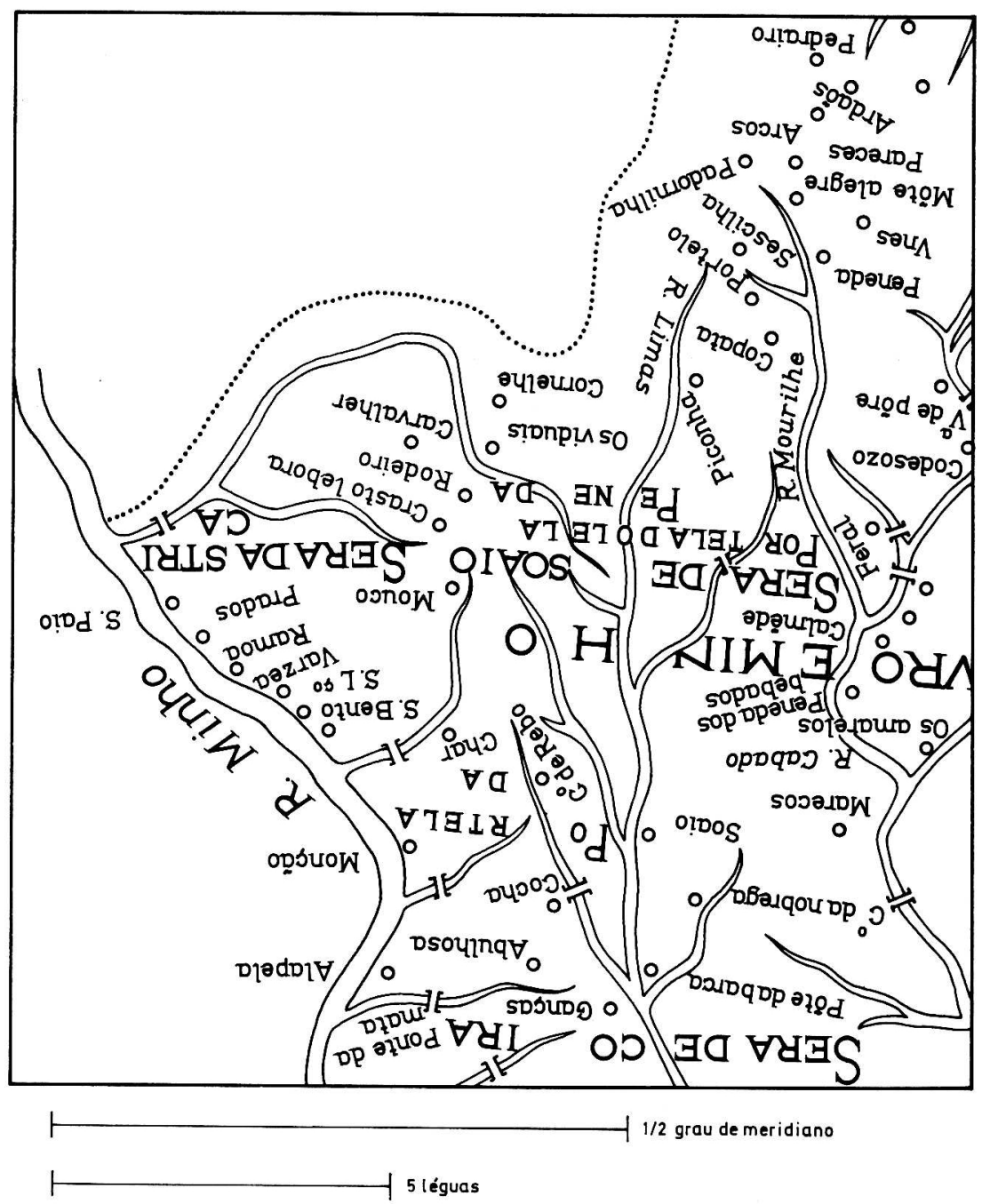

Fig. 5 - Ampliação do mapa de Portugal de Fernando Álvaro Seco (1560). O mapa foi redesenhado, para melhor leitura, mas a localização dos topónimos foi exactamente respeitada, bem como o facto do topo do mapa corresponder ao Oeste. A posição, à primeira vista estranha, deste mapa na página é destinada a permitir a comparação com a figura 6 .

Fig. 5 - Enlargement of the area in Figure 6 of the Fernando Alvaro Seco map of Portugal (1560). The map was redrawn so as to be more easily read but the localisation of toponyms is exactly the same.

diam pessoas possuidoras de «mapas mentais» dos caminhos, suficientemente amplos e exactos para poderem aconselhar os viajantes estranhos ao país. Estes descem durante uma boa hora, até atingir uma ponte de madeira, de apenas dois pés de largura e onde cada um tem de andar por seu turno, que dominava de muito alto um rio apavorante, que Bronseval chama curiosamente «Bondreuil» mas que é o Cávado. Depois de ultrapassar outra serra, larga de 2 léguas, 


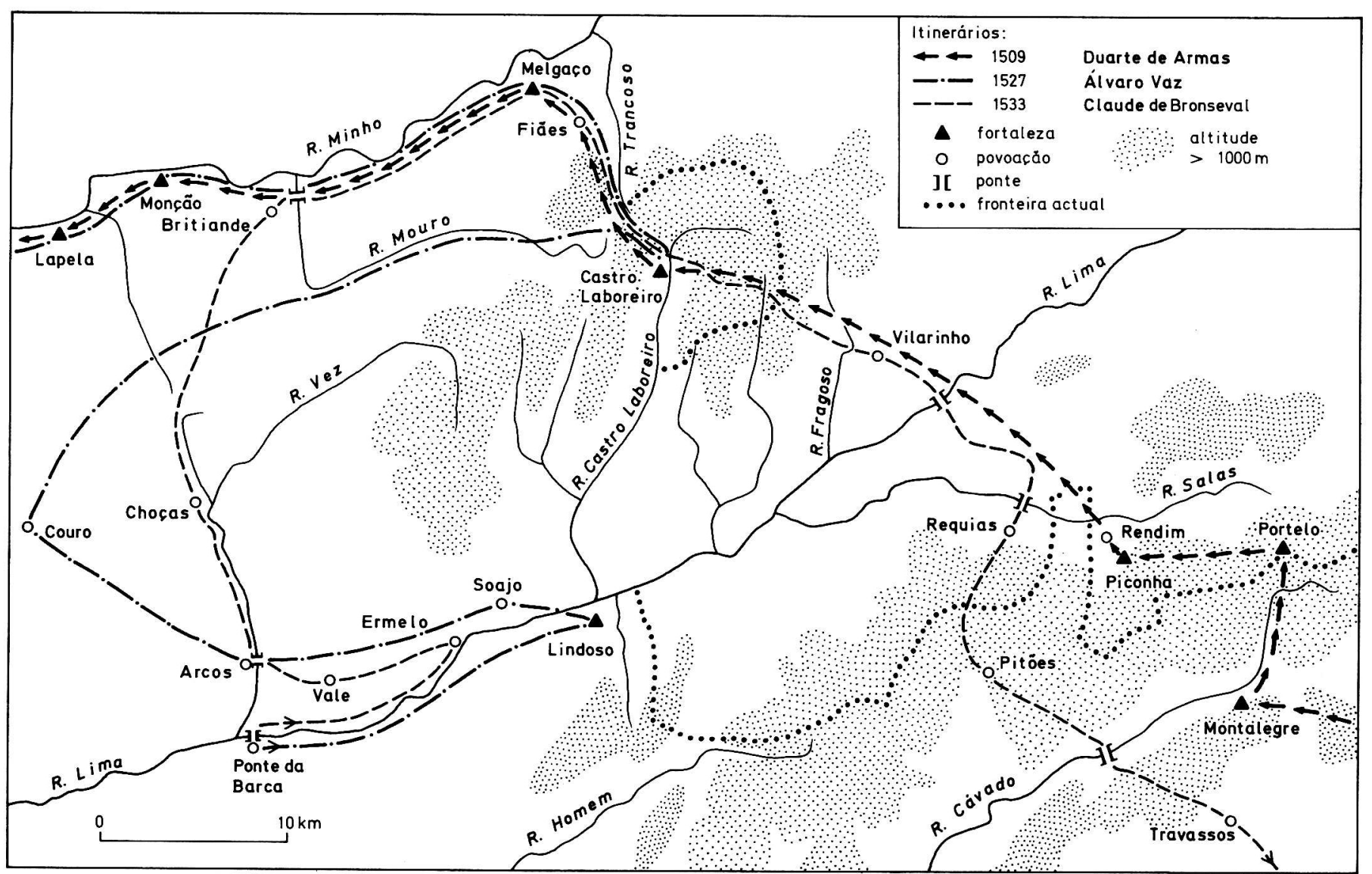

FFig. 6 - Os itinerários do começo do século XVI nas serras do extremo Norte de Portugal, segundo ALMEIDA, 1943; BRONSEVAL, 1970; ARMAS, 1997 e DIAS, 1999.

Fig. 6 - Early 16th century itineraries in the serras of the extreme north of Portugal according to ALMEIDA, 1943; BRONSEVAL, 1970; ARMAS, 1997 and DIAS, 1999. 
atingem Travaissa (Travassos da Chã), onde se reconfortam com um copo de vinho. A descrição do caminho vai prosseguindo, sendo o "Terva» (Tâmega) franqueado por uma pequena barca, e chegam a Vila Real no dia 30, depois de ter seguido um vale muito comprido. Note-se, neste extracto muito resumido, a presença de pontes, mesmo que rudimentares, nos itinerários com certa importância inter-regional; note-se também que muitas das pontes que $\begin{array}{llllllllll}B & \mathrm{r} & \mathrm{O} & \mathrm{n} & \mathrm{s} & \mathrm{e} & \mathrm{v} & \mathrm{a} & \mathrm{l}\end{array}$ cita, neste e noutros percursos, não se encontram representadas no mapa de Fernando Álvaro Seco.

Mas, voltando ao problema mais restrito da representação dos rios na região das Serras da Peneda e do Gerês (fig. 1 e 5), verifica-se que a fraca qualidade do desenho hidrográfico está aí indubitavelmente ligada à pouca utilização dos itinerários através duma região despovoada e insegura. O Lima parece, no mapa, nascer a pouca distância de Piconha, correspondendo este traçado ao do seu afluente, o Rio Salas, quando o rio principal se forma, na realidade, cerca de $40 \mathrm{~km}$ mais a NE. O Lindoso não aparece no mapa e o Soajo encontra-se colocado erradamente na margem esquerda do rio e, paradoxalmente, muito a jusante da Serra de mesmo nome. Pelo contrário, o Rio de Mouro, afluente do Minho, atravessado por uma ponte no seu curso inferior, apresenta um desenho anguloso bastante exacto, que confirma a frequência habitual do seu vale superior, como foi sugerido acima, a propósito do trajecto de Álvaro Vaz, em 1527. Quanto à drenagem da parte oriental da Serra da Peneda, ela é constituída no mapa por segmentos invertidos, arbitrariamente reunidos numa confluência que parece corresponder à larga portela seca de Lamas de Mouro, a NW de Castro Laboreiro.

Esta parte da raia galega devia ser, no começo do século XVI, uma terra meio abandonada pela administração central mas, ao mesmo tempo, pouco perigosa do ponto de vista militar. A sua medíocre representação cartográfica está em forte contraste com a cuidadosa e pormenorizada imagem da faixa fronteiriça oriental que o mesmo mapa fornece, faixa de confronto tradicional entre os exércitos castelhano e português.

\section{UM DOCUMENTO CARTOGRÁFICO DE VALOR, MAS POUCO CONHECIDO DOS ERUDITOS NACIONAIS}

Em estudo anterior (DAVEAU, 1984, fig. 4) já se fez a análise da representação cartográfica antiga da rede hidrográfica da região de Coruche (fig. 2). Verificou-se então a validade, exacta até ao mínimo pormenor, dos traçados complexos e instáveis do Sorraia e afluentes, no lugar de passagem de um dos itinerários terrestres então mais frequentados de Portugal, como confirmam, aliás, as numerosas pontes representadas no mapa, entre o vale do Tejo e a cidade de Évora (fig. 1). A verificação da validade do traçado dos rios próximos de Coruche foi tornada possível graças, uma vez mais, ao testemunho de 
Claude de Bronseval, rectificando-se também aqui pormenores da interpretação topográfica anterior do texto, proposta pelo tradutor e anotador (BRONSEVAL, 1970). Em contraponto, a mesma região permite verificar uma ligação hidrográfica inexacta, desenhada através do espaço plano e deserto da charneca situada ao norte de Coruche: a Ribeira de Magos foi considerada pelo cartógrafo como confluindo no Tejo em Muge, em vez de Salvaterra.

Portanto, se o mapa de Fernando Álvaro Seco tem algumas fraquezas no traçado da rede hidrográfica, quase sempre nos recantos menos percorridos do reino, ele é, no conjunto, um documento de valor. Ora, estudos anteriores (Daveau, Ribeiro, 1986; Daveau, no prelo, a) já mostraram que os letrados do século XVI que se interessavam pela descrição corográfica do País e que viajavam amiúde entre os grandes centros administrativos e universitários, não parecem ter conhecido o mapa de Fernando Álvaro Seco ou não lhe atribuiram valor documental. Tanto André de Resende, no De Antiquitatibus Lusitaniae, publicado em 1593 mas que circulou bem mais cedo em forma manuscrita (Resende, 1996), como Duarte Nunes de Leão na Descrição de Portugal, publicada em 1610 mas escrita nos últimos anos do século XVI (LEÃO, 2. ${ }^{\mathrm{a}}$ ed., 1785 e no prelo), dedicaram capítulos inteiros à apresentação dos rios de Portugal. Mas os rios, que interessaram estes eruditos, apenas em parte coincidem com os que aparecem no mapa de Fernando Álvaro Seco (comparem-se a fig. 1 do pre-sente estudo com as fig. 3 e 4 de Daveau, Ribeiro, 1986).

Duarte Nunes de Leão demonstra ter, às vezes, conhecimentos que faltam no mapa de 1560, por exemplo quando indica que o Lima nasce «de uns lugares apaulados entre a cidade de Orense e a vila de Monte Rei» ou quando nomeia o Caia, o Ceira e outros rios. No entanto, comete vários erros, mas diferentes dos que aparecem no mapa de Fernando Álvaro Seco. O Sado é, para ele, um rio muito especial, que «não tem nascimento algum próprio, mas é um ajuntamento de águas das ribeiras de Exarama, de Odivelas, de Garcia Menino, de Santa Detença a tempo que já vão muito grandes, por as águas que colheram de muitas ribeirinhas, regatos e fontes, e se ajuntam todos em um certo passo, do qual se faz um rio grande que se chama Sado». Esta descrição não corresponde, nem à realidade (fig. 4), nem ao mapa de Fernando Álvaro Seco (fig. 2).

Quanto ao Neiva, Duarte Nunes de Leão declara que «este rio por si não entra no mar mas entra em companhia do rio Cadavo em que se mete». O mesmo erro aparecia já em Resende e, muito antes, na Suma de Geografia do Dr. João de Barros, escrita em 1548 e que corria então manuscrita (BARRos, 1919). Os eruditos corógrafos copiavam-se uns aos outros, mas não parecem ter consultado o mapa de Fernando Álvaro Seco, perfeitamente correcto neste lugar (fig. 1).

No entanto, enquanto Resende faz do Rio Sôr um dos constituintes do Sorraia, apoiando assim uma tentativa de demonstração toponímica, Duarte Nunes de Leão afasta-se desta lição e afirma que o rio Sôr «se mete no Tejo em Abrantes, imaginando portanto uma viragem para norte em Ponte de Sôr, através do vale do rio Torto, ou seja, por um dos itinerários então mais frequen- 
tados entre Évora e a região de Tomar. Mesmo num ponto onde se afastou da sua fonte literária habitual e respeitada, Duarte Nunes do Leão não teve a ideia de consultar um mapa que era tão fácil encontrar, desde 1570 pelo menos, por estar incluído no Theatrum Orbis Terrarum de Abraham Ortelius. Luís Mendes de Vasconcelos evocará aliás, em 1608, um velho fidalgo que conheceu na sua juventude, «douto em letras humanas e algumas artes de estima», que encontrou um dia «com Abraham Ortélio nas mãos» (VAsConcelos, 1803).

\section{OS LEVANTAMENTOS CARTOGRÁFICOS TERRESTRES EM PORTUGAL NO SÉCULO XVI}

Não se encontrou, até hoje, documentação alguma sobre as técnicas de levantamento e elaboração do mapa de Portugal, que foi gravado em Roma e que tem a data de 1561 (FERREIRA et al., 1956-57). Espera-se que o presente estudo das características da sua rede hidrográfica traga um primeiro contributo à compreensão deste assunto. Mas, antes de apresentar possíveis conclusões ou pistas de estudo, parece conveniente apreciar o que nos ensinam outros documentos, de data próxima, que conservaram a descrição de levantamentos de itinerários, capazes de terem sido utilizados por cartógrafos. Dois deles já foram citados: o itinerário de Duarte de Armas, que se datou de 1509 (Castelo Branco, em ARMAS, 1997) e o de Bronseval, escrito em 1532-33 (Bronseval, 1970). Outra compilação de itinerários merece também atenção, a Descripción y Cosmografía de España por Fernan Colón, recentemente publicada (Colón, 1988). Esta compilação de itinerários inclui, com efeito, alguns percursos portugueses.

O itinerário de Bronseval tem muito interesse, como se mostrou. Mas, realizado por um estrangeiro, era destinado aos arquivos da Ordem de Cister, para facilitar eventualmente uma futura viagem de inspecção do Abade aos mosteiros dependentes. Não foi, com certeza, conhecido em Portugal na altura. Entre outros aspectos, demonstra que o seu autor não terá utilizado mapas para organizar a sua viagem e que nunca se preocupou com a orientação dos caminhos percorridos mas, apenas, com as distâncias (em tempo) e com as dificuldades do terreno, do alojamento e da restauração.

O itinerário de Duarte de Armas, sensivelmente anterior (1509), não parece também ter sido destinado directamente à realização de um documento cartográfico de conjunto. No entanto, é muito mais próximo que o diário de Bronseval do tipo de recolha documental directamente utilizável por um cartógrafo: regista seca e sistematicamente as distâncias, o tipo de terreno, os rios atravessados e as pontes. Mas falta nele qualquer indicação de orientação, ao contrário do que acontece nas duplas vistas das fortalezas que desenhou, onde se indica sempre de qual "banda» a vista foi tirada, como se o autor tivesse então utilizado uma bússola. Não será este levantamento de itinerário mais que uma obra preliminar em relação ao primeiro mapa de Portugal, mas é já 
claramente indicativo do desejo e da capacidade do poder central de reunir uma documentação sistemática, mas incidindo apenas, nesta altura, sobre a faixa fronteiriça.

Os itinerários recolhidos por Fernan Colón, provavelmente entre 1517 e 1523 , não foram ainda estudados sistematicamente. Foram apenas citados por Gabriel Marcel (1899) e sucintamente caracterizados por Gonçalo de Reparaz (1943: 62-63). Publicaram-se em 1988, sem comentários, os que se encontram na Biblioteca Colombina de Sevilha e na Biblioteca Nacional de Madrid. Ora, interessam não apenas como exemplos comparativos do tipo de levantamentos que se fazia na época mas, mais directamente, por incluirem vários trechos portugueses, que mereceriam um estudo aprofundado. Encontram-se, na compilação, descrições referentes às regiões de Évora e do Alto Alentejo, da região fronteiriça a leste do Sabugal, de diversos lugares trasmontanos e, também, da região de Lisboa e Almeirim. A título puramente preliminar e exemplificativo, cita-se um extracto da descrição da região de Évora (1988, I: 237), onde aparecem rios: «ebora es çibdad de $300 \mathrm{v}$. e es en portogal e tiene fortaleza e pasa junto com la çibdad un rrio dicho cuerpo d'hombre e fasta viana ay $3 \mathrm{l}$. de tierra algo dobrada e a 2 l. de ebora pasa un rrio dicho pardielas por vado que corre a la mano dizquierda e fasta monte mor ay $3 \mathrm{l}$. llanas e fasta ebora monte $4 \mathrm{l}$. llanas e para subir a ebora monte subimos una questa arriba questara media légua...».

Outro importante conjunto documental que poderia, a priori, ter servido para a realização do primeiro mapa de Portugal é o Numeramento dos moradores das seis comarcas portuguesas, levado a cabo de 1527 a 1532 pelo poder central (FreIRE, 1905-09; COLlaço, 1929). A preocupação de descrição espacial aparece sobretudo nele a partir das novas instruções reais, datadas de 12 de Maio de 1530, que mandavam registar a distância entre as sedes de concelho, e que se concretizaram essencialmente na descrição que Nuno Gonçalves forneceu, em 1532, das terras das Ordens militares do Alentejo, indicando sistematicamente a orientação dos diversos confrontos (DAVEAU, no prelo, b). Mas a determinação destas orientações continua fruste, encontrando-se, com poucas excepções, o horizonte dividido apenas em 8 sectores de $45^{\circ}$ cada um, o que parece muito insuficiente para se construirem triângulos fechados entre as sedes de concelhos vizinhos.

Aliás, as localidades inscritas no mapa de Fernando Álvaro Seco estão longe de corresponder preferencialmente às sedes administrativas do Numeramento. Encontra-se ainda em fase incipiente o indispensável e minucioso trabalho de confronto dos dados de povoamento contidos nestes dois documentos e no Códice de Hamburgo, outro documento que vai ser caracterizado a seguir. Mas parece já claro que a recensão dos moradores e o levantamento do mapa de Fernando Álvaro Seco não foram empreendimentos estreitamente interligados. Terão sido realizações mais ou menos contemporâneas e resultantes de um mesmo ambiente de centralização e racionalização administrativas, mas parecem devidas ao esforço de grupos independentes de técnicos e organizadores. Enquanto o Numeramento foi, claramente, obra da administração judi- 
e diplomatas, preocupados com a sempre renascente rivalidade com a coroa de Castela. Como se verifica ao estudar a rede hidrográfica, a qualidade do mapa de 1560 é nitidamente melhor na faixa raiana oriental, a mais exposta às invasões, o que apoia a hipótese duma realização diplomático-militar.

Para encontrar um documento que ilustre explicitamente o levantamento dum mapa corográfico, é preciso chegar a 1610, quando o cartógrafo português João Baptista Lavanha começou a preparar o mapa do Aragão (LABAÑA, 1895; HERNANDO, 1996). Tanto a correspondência referente à preparação do mapa, como, sobretudo, o próprio diário de campo de Lavanha, permitem saber como procedeu o cartógrafo. A técnica de levantamento não parece ter evoluído muito desde o ano de 1524, quando se publicou o precioso manual prático de Apiano, em parte relativo à arte topográfica, que conheceu nos anos seguintes numerosas edições, em várias línguas (APIANo, 1548; ver também FINE, 1532 e DAinville, 1970). Quando muito, o que terá progredido, é a qualidade dos instrumentos de medição utilizados. Lavanha usou um goniómetro melhorado, que lhe permitia estimar os ângulos até 1/2 grau de precisão. A parte principal do seu trabalho de levantamento foi a realização de múltiplas observações de paisagem a partir de pontos altos, anotando-se os ângulos e compilando-se as distâncias avaliadas pelos "práticos», conhecedores da região, que o acompanhavam. De caminho, ia tomando muitas outras notas, sobre as distâncias

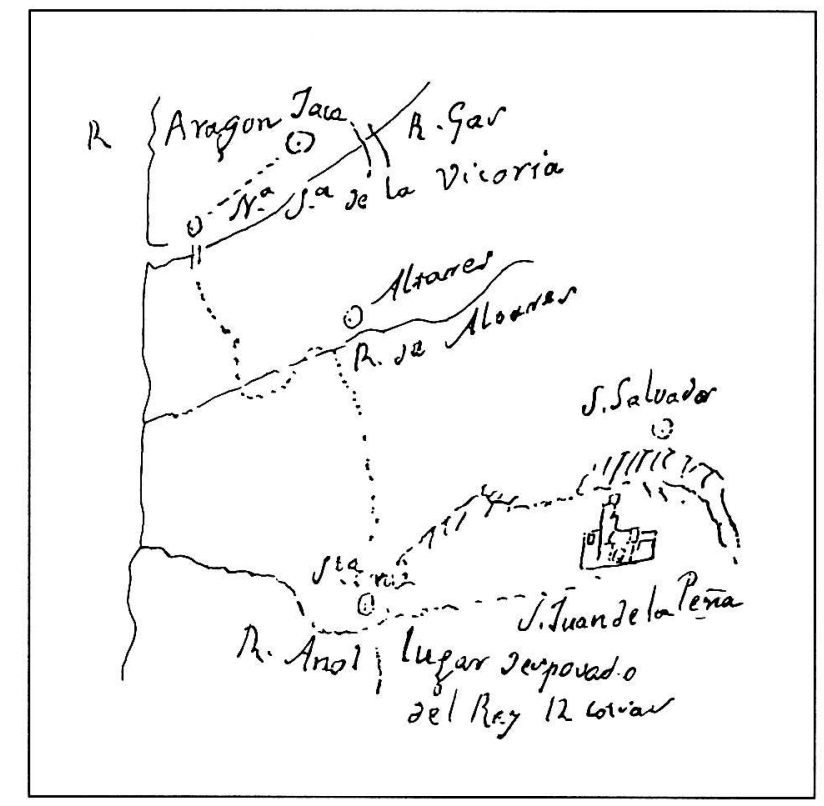

Fig. 7 - Esboço de João Baptista Lavanha, ilustrando a sua descrição dos rios da região de Jaca, em Aragão (LABAÑA, 1895: 43).

Fig.7 - Sketch by João Baptista Lavanha to illustrate his description of the rivers in the Jaca district in Aragon (LABAÑA, 1895: 43). 
havam. De caminho, ia tomando muitas outras notas, sobre as distâncias percorridas e sobre tudo o que via, à direita e à esquerda. O cálculo das distâncias verdadeiras, ditas «directas», resultava, depois, de um moroso trabalho de gabinete, onde todas as informações recolhidas eram entrecruzadas. É interessante verificar que foi ainda este mesmo método que utilizou o naturalista Canavilles no fim do século XVIII, quando levantou, em 1791, o mapa do Reino de Valência (CANAVIlles, 1795-97; 2. ${ }^{\mathrm{a}}$ ed., 1958: 1-2)

Relativamente aos rios, podem servir de exemplo as anotações de Lavanha referentes aos arredores de Jaca, recolhidas em 28 de Novembro de 1610 e escolhidas por serem acompanhadas dum pequeno esboço (fig. 7). Lê-se o seguinte na relação: «fui a S. João de la Peña que são 2 léguas e meia de Jaca (...) prolongando-se a Peña para ponente, se vai levantando suavemente, té uma ponta muito mais alta que o restante, onde está uma ermida do Salvador (...) da qual se descobre um grande espaço de terra e de montes». Depois de anotar a orientação e distância dos lugares daí visíveis, Lavanha prossegue: «Passa pelo lugar [de Santa Cruz] à mão esquerda um ribeiro que se chama Anol, que entra em Aragão de lá a uma légua. E por este caminho para Jaca se passa muitas vezes um rio que se chama de Ataros [assim na edição de 1895, mas Atares na de Garcia Mercadal (1959), enquanto se lê Altares e R. de Alvares no esboço (fig. 7)], o qual passa por este lugar à mão direita e nasce acima de uma légua $\mathrm{e}$ entra em Aragão uma légua antes de Jaca, e meia légua antes entra no mesmo Aragão o rio Gas, que ali tem ponte.»

Os documentos utilizados pelo autor do mapa de 1560 não devem ter sido muito diferentes dos apontamentos de Lavanha: observações anotadas ao longo de itinerários, informações de práticos da terra, apreciação grosseira das distâncias. O que progrediu bastante, entre as duas épocas, foi a técnica de medições dos ângulos a partir dos pontos altos. As medições obtidas eram, a seguir, confrontadas e corrigidas no gabinete, para obter um mapa o menos distorcido possível, sendo as distâncias «directas» entre as povoações avaliadas então por aproximação. Mas o levantamento do curso dos rios continuava bastante fruste, procurando saber-se, antes de tudo, em que sentido corriam e onde se situavam as confluências.

Como já se disse, existe uma lista de cerca de 1500 topónimos referentes a Portugal e arrumados alfabeticamente pela primeira letra, contida num códice da Biblioteca de Hamburgo. Para a maior parte destes lugares, são indicados valores de longitude e latitude, que apenas podem ter sido graficamente determinados a partir dum mapa anteriormente desenhado. Kevin Kaufman (1988) datou a lista do período 1525-36, quase coincidente portanto com a realização do Numeramento (1527-32). Está apenas encetado o indispensável e moroso confronto do conteúdo toponímico dos dois documentos, que a publicação em curso do Dicionário Corográfico do Portugal Quinhentista por J. J. Alves Dias (1999-) irá facilitar. Também será indispensável confrontar estas duas séries de dados com o levantamento toponímico do mapa de 1560, já realizado por Joaquim da Silveira (em FerReira et al., 1956-57). Mas pode notar-se, desde 
já, que a lista de Hamburgo não inclui nenhum nome de rio, nem de foz ou confluência, enquanto comporta bastante nomes de acidentes litorais, de paúis e até de pontes, e ainda uma lista anexa de serras. Outro problema para estudar.

\section{ALGUMAS CONCLUSÕES PROVISÓRIAS E PISTAS DE INVESTIGAÇÃO}

1. As fontes possíveis do desenho da rede hidrográfica no mapa de Fernando Álvaro Seco datado de 1561. A rede representada parece resultar da compilação e harmonização de dados extraídos de vários itinerários, com características originais diferentes, sendo uns mais virados para a descrição dos caminhos (e, logo, das pontes e barcas que permitiam atravessar os rios, mas sem grande preocupação de os nomear), outros mais especificamente hidrográficos, registando até afluentes muito pequenos, não raro designados pelo nome, mesmo em lugares onde não interferiam com itinerários frequentados. No entanto, a densidade bastante regular da rede hidrográfica à escala nacional faz pensar que alguns levantamentos complementares terão talvez sido realizados na altura da preparação do mapa, para assegurar uma densidade e homogeneidade suficientes à informação utilizada, enquanto certa selecção da informação disponível ocorria nas regiões especialmente ricas em informação.

2. Influência dos contrastes regionais do relevo e do clima de Portugal. O relevo têm nítidas relações, mas bastante complexas e apenas indirectas, com a qualidade da representação da rede hidrográfica no mapa de 1561. Já se verificou que os erros de percurso e de confluência ocorrem sobretudo nas regiões de planície, onde o recorte do relevo não indica claramente ao observador o traçado e a direcção dos cursos de água. Mas, por outro lado, as regiões de relevo muito recortado ou escarpado têm tendência a ser negligenciadas ou até esquecidas pelo cartógrafo, por serem pouco frequentadas pelos viajantes e portanto mal documentadas. É indirectamente, através das formas de utilização do espaço pelos habitantes, que a diversidade orográfica tem reflexos na representação hidrográfica. Os rios perenes do Norte parecem ter sido mais regularmente registados que os cursos episódicos do Sul, que prejudicavam raramente a circulação dos viajantes.

3. O significado da densidade das pontes. Numerosas são as pontes assinaladas no mapa de 1561 (fig. 1), mas é interessante notar que este aspecto do mapa dito de Roma foi o menos respeitado pelos mapas derivados, sobretudo pelo exemplar de Antuérpia (1565), que eliminou por completo as pontes, e mesmo pelo mapa incluído no Theatrum Orbis Terrarum (1570), réplica muito próxima do mapa de 1561 no conjunto, mas que comporta bastantes negligências na reprodução das pontes. As duas edições flamengas destinavam-se a um vasto público, na maior parte estrangeiro e que, desejoso de dispor de uma imagem de conjunto de Portugal, não tinha particular interesse nas condições 
de circulação dentro do País. A presença de numerosas pontes no mapa de 1561 parece portanto mais uma herança do documento de base utilizado, que uma característica conscientemente escolhida para interessar o Cardeal Sforza, a quem o mapa foi dedicado.

A desigual densidade regional das pontes não parece aliás corresponder à sua verdadeira repartição regional no reino. Segundo Mestre António (1512) havia, nos rios de Entre Douro e Minho, «perto de duzentas pontes de arcos de pedras lavradas, as melhores que há em Espanha em tão pouco separada terra, que à légua e meia desta vila de Guimarães há vinte pontes de arcos de pedra lavrada, afora outras muitas de pau e de pedra que não são lavradas.» Ora, não se contam, no mapa de Fernando Álvaro Seco, mais de 30 pontes em toda a província do Entre Douro e Minho, e nenhuma delas se situa perto de Guimarães. Verificou-se também que, nos itinerários percorridos por Claude de Bronseval em 1532-33, acima exemplificados, ele indica a presença de numerosas pontes, mesmo que nem sempre seguras, as quais não aparecem também no mapa. Mesmo uma ponte que considerou muito boa, a «pulchro ponte» que atravessava «le Rieu de Vaisse» em «Villadarcha» (o Rio Vez em Arcos de Valdevez) não aparece no mapa, a menos que seja a que se encontra perto de Choças, mas neste caso muito deslocada para montante (fig. 1 e 5).

A densidade das pontes diminui muito sensivelmente no sul do País, no Baixo Alentejo e Algarve. Uma razão climática intervém, sem dúvida, neste contraste, como já se disse. Os rios do Sul têm, a maior parte deles, um regime tão irregular que se passam a vau sem problema durante a maior parte do ano ou, até, deixam de correr durante meses. Para quê construir pontes nestas condições?

No ponto 6, irão ser ainda evocadas outras possíveis determinantes da repartição regional das pontes.

4. Erros na orientação dos vários ramos da rede hidrográfica. A orientação é o aspecto mais fraco da primeira representação cartográfica conhecida dos rios portugueses. Retoma-se o exemplo acima utilizado, o do Rio Vez, que corre, depois de sair da serra, praticamente de norte a sul (fig. 1). Ora, no mapa de 1561 (fig. 5), tem um curso rigidamente orientado ENE-WSW até confluir com o Lima. E não é caso excepcional: uma distorção de mesmo tipo nota-se, por exemplo, nos arredores de Bragança, relativamente às redes do alto Sabor e Tua. Numerosos outros casos se podiam citar, entre os quais o do curso do Tejo avulta pela dimensão e pelas relações ambíguas que tem com a distorção de conjunto do mapa.

Estes graves erros de orientação significam que os levantamentos (ou parte deles) foram feitos com pouca preocupação de medir as orientações, usando-se apenas uma grosseira referência aos pontos cardeais principais (nascente, poente, meio-dia e norte), rapidamente apreciados pela observação da posição do sol no céu ao longo do dia, ou já com o uso rudimentar da bússola, permitindo dividir o horizonte em 8 a 16 sectores. Foi possível mostrar que a primeira 
destas duas técnicas foi provavelmente a que usou Álvaro Vaz, quando realizou o Numeramento de Entre Douro e Minho em 1527, mas que a segunda já teria sido, possivelmente, utilizada em 1532, no Alentejo, por Nuno Gonçalves ou, antes, pelo autor de um levantamento cartográfico que teria aproveitado (Daveau, no prelo, b).

As deformações de conjunto do mapa de Fernando Álvaro Seco constituem um importante problema, já reconhecido e discutido (FerReIRA et al., 1956-57; ver também KAUFMAN, 1988, relativamente ao mapa correspondente à lista do Códice de Hamburgo). Mas ainda não parece possível decidir se estas deformações de conjunto foram causa ou consequência da má orientação de muitos dos rios e, também, das relações nem sempre correctas do traçado destes com a posição das povoações ribeirinhas.

5. Relação espacial entre os cursos de água e as povoações ribeirinhas. Esta relação não foi ainda estudada sistematicamente. Apenas numerosas observações avulsas permitem afirmar que existem muitos erros nas localizações de pormenor. Há povoações implantadas na margem errada dos rios ou, à

vezes, permutas entre lugares vizinhos. Frequentemente, nem se conseguem localizar precisamente os centros habitados em relação aos cursos de água, sobretudo quando se trata de centros importantes, representados por símbolos vultuosos, ocupando no mapa um espaço desproporcionado, que atinge facilmente uma légua. Tanto mais que o desenhador teve a preocupação de destacar melhor estes símbolos, afastando-os dos riscos paralelos que representam o rio próximo.

É ainda difícil dizer se o levantamento dos cursos de água e a escolha dos lugares habitados destinados a aparecer no mapa foram sistematicamente feitos ao mesmo tempo. Se os dados recolhidos no Numeramento foram utilizados na elaboração do primeiro mapa corográfico de Portugal - facto que considero pessoalmente como bastante duvidoso -, eles tiveram de ser cruzados com informações de outras origens, já que as alusões aos rios são muito esporádicas nas várias partes do Numeramento. Lembre-se, aliás, que a lista contemporânea do Códice de Hamburgo não comporta rio algum, como se a toponímia e a hidronímia relevassem, nesta altura, de interesses e preocupações diferentes. É provável que a realização de uma série de análises aprofundadas do conteúdo do mapa, à escala de pequenas regióes, permita esclarecer melhor este problema fundamental das ligações genéticas entre os dois elementos constitutivos do mapa de Fernando Álvaro Seco, os rios e as povoações.

6. Aspectos económicos e aspectos militares. Já se mostrou, no mapa em estudo, uma indubitável preocupação com os assuntos militares (MAGALHÃES, 1993: 20), que se traduziu, sobretudo, na melhor representação da rede hidrográfica da faixa oriental do País, considerada como mais exposta a potenciais investidas dos exércitos castelhanos, ainda que a última batalha campal datasse 
já de 1476. Mas a preocupação em definir uma clara linha de separação entre os portugueses e os seus vizinhos foi patente em toda esta época (Id.: 24-33), bem como o cuidado em manter e consertar as fortalezas próximas da raia. Pelo contrário, a representação das pontes não parece resultar principalmente de preocupações militares. Não se nota, com efeito, nenhuma relação sistemática, positiva ou negativa, entre a sua presença no mapa e a proximidade da fronteira ou as vias habituais das invasões castelhanas.

No plano económico e social, certos eixos de circulação terrestre e algumas áreas peri-urbanas, com vida e circulação mais intensas, deixam-se individualizar pela multiplicidade das pontes. Estas enquadram estreitamente Coimbra e multiplicam-se excepcionalmente ao longo da vala de Alpiarça, frente a Santarém, como que para abrir acessos cómodos aos vastos espaços de charneca da margem esquerda do Tejo, terrenos de caça preferenciais do Rei e da Corte durante o Inverno.

Mas não se distinguem sistematicamente, no mapa, os rios navegáveis dos outros cursos de água e só esporadicamente aparecem indicações neste sentido. $\mathrm{Na}$ parte vestibular do Tejo, as modalidades de representação do estuário parecem tomar em conta a acessibilidade aos barcos de mar e os esteiros navegados são nitidamente distinguidos (DAVEAU, 1994: 27-28). Também está indicado o Porto da Lama, término da navegação no Sado mas nos outros rios, mesmo nos maiores, este tipo de indicação, tão importante, falta por completo.

7. Alguns dados sobre o mapa de Portugal com data de 1561 e sobre o seu verdadeiro autor. Quem será o cartógrafo responsável pelo conteúdo do mapa difundido em Roma (ou de um modelo anterior deste), que o terá concebido e construído a partir de informações recolhidas no terreno, talvez em parte por ele, talvez sobretudo por outros? Este cartógrafo teve, evidentemente, um difícil papel de escolha e interpretação dos dados que estavam ao seu dispor. É provavelmente ele o responsável pelos numerosos erros de confluência que marcam, por exemplo, a bacia do Sado. Confrontado com uma informação desigualmente densa, resultante de diversas descrições de itinerários, teve de interpretar e interpolar, nem sempre de modo muito satisfatório.

Será este construtor do mapa, responsável pelo seu conteúdo, o próprio e enigmático Fernando Álvaro Seco (VASCONCELOS, 1930), a quem o mapa com a data de 1561 é atribuído ? Ou a intervenção de Seco terá sido apenas tardia e limitada a tarefas finais de selecção e de desenho, destinadas à realização de uma versão de prestígio, derivada de um mapa manuscrito anterior ?

Não parece ter chegado ainda a altura própria para se retomar uma discussão de conjunto das relações que ligam o mapa impresso, com data de 1561, aos evidentes passos anteriores do levantamento cartográfico de Portugal (vejam-se Cortesão, 1935; Reparaz, 1943; Ferreira et al., 1956-57; Cortesão, Mota, 1960; Alegria, Garcia, 1995). Parece indispensável prosseguir, antes, o estudo da lista toponímica com coordenadas geográficas do Códice de Hamburgo, confrontá-la com os dados do Numeramento e procurar caracterizar 
melhor o grupo dos matemáticos, cartógrafos, militares e cortesãos, que podem ter participado no primeiro levantamento cartográfico do País.

Pode afirmar-se desde já que o processo de produção do mapa de Portugal que serviu de preciosa oferta diplomática, encomendada por Aquiles Estaço e destinada ao Cardeal Camareiro Guido Ascânio Sforza, foi um processo complexo, que incorporou, sem dúvida, dados cartográficos muito anteriores à importante embaixada em Roma de Lourenço Pires de Távora. A Quinta da família deste encontra-se bem destacada no mapa, perto da Caparica, ao sul da foz do Tejo, como, mais modestamente, a Quinta dos Secos, perto de Tomar. Esta embaixada decorreu de 8 de Junho de 1559 a 24 de Abril de 1662 e permitiu debater e resolver importantes aspectos das relações entre Portugal e a Santa Sé. Formalmente, ela culminou no dia 20 de Maio de 1560, quando a Oração de Obediência ao Papa Pio IV do jovem Rei D. Sebastião (sendo D. Catarina regente) foi proferida em latim, em nome do embaixador, pelo próprio Aquiles Estaço, promotor da realização do mapa (BRANCO, 1957).

Ora, repare-se que o exemplar dito de Roma tem uma dedicatória datada do 13 das calendas de Junho (ou seja, de 20 de Maio) de 1561, enquanto o exemplar de Antuérpia apresenta a data de 13 das calendas de Junho de 1560. A data da Oração de Obediência parece esclarecer definitivamente a polémica que se levantou acerca do ano da dedicatória do mapa, confirmando a data de 1560 . O que não impede que o mapa dito de Roma tenha sido gravado e impresso no ano seguinte ou, até, mais tarde. De qualquer modo, a elaboração do exemplar, provavelmente manuscrito, que serviu então de oferta diplomática, é com certeza posterior à do conteúdo do mapa original, que serviu de modelo.

\section{BIBLIOGRAFIA}

Alegria, F.; Garcia, J. C. (1995) - Aspectos da evolução da Cartografia portuguesa (séculos XV a XIX)», em Dias, Maria Helena, Os Mapas em Portugal, Cosmos, Lisboa: 27-84.

AlmeidA, J (1943) - Reprodução Anotada do Livro das Fortalezas de Duarte Darmas, Editorial Império, Lisboa.

AnTónio, M. (1959) - Tratado sobre a província d'Amtre Douro y Minho e suas avondanças, Boletim Cultural da Câmara Municipal do Porto, 22, Porto: 441-460 [1512].

Apiano, P. (1548) - Libro de la Cosmographia, Antuérpia [1524].

ARmas, D. (1997) - Livro das Fortalezas, Arquivo Nacional da Torre do Tombo, Edições Inapa, Lisboa, $2 .^{\mathrm{a}}$ edição.

Baptista, J. M. (1874-79) - Chorographia Moderna do Reino de Portugal, Lisboa, 7 vols.

Barros, J. (1919) - Geografia d'Entre Douro e Minho e Trás-os-Montes, Porto [1548].

Branco, J. (1957) - Os discursos em latim do humanista Aquiles Estaço, Euphrosyna, Lisboa, I: $3-23$.

Bronseval, F. C. (1970) - Peregrinatio Hispanica (1531-1533), Paris, 2 vols., 853 p. 
Canavilles, A. J. (1958)-Observaciones sobre la Historia Natural, Geografía, Agricultura, Población y Frutos del Reyno de Valencia, Madrid, 2. ${ }^{a}$ ed. C.I.S.I.C., Zaragoza, 2 vols. [1795-1797].

Collaço, J. M. (1929) - Cadastro da População do Reino (1527). Actas das Comarcas Damtre Tejo e Odiana e da Beira, Lisboa, 223 p.

Colón, F. (1988)-Descripción y Cosmografía de España por Fernan Cólon, Padillo Libros, Sevilha, 3 vols.

Cortesão, A. (1935) - Cartografia e Cartógrafos Portugueses dos Séculos XV e XVI, Lisboa, 2 vols.

CoRtesão, A.; Mota, A. T. (1960) - Ver PMC.

Dainville, F. (1970) - How did Oronce Fine draw his large map of France ?, Imago Mundi, 24: 49-55.

Daveau, S. (1984) - Géographie historique du site de Coruche, étape sur les itinéraires entre Évora et le Ribatejo, Revista da Faculdade de Letras, 2, Lisboa: 115-135.

Daveau, S. (1994) - A foz do Tejo, palco da história de Lisboa, em Lisboa Subterrânea, Lisboa: 24-30.

Daveau, S. (no prelo, a) - O conteúdo geográfico da Descrição do Reino de Portugal, em LeÃo, Duarte Nunes, Descrição do Reino de Portugal.

Daveau, S. (no prelo, b) - A descrição territórial no Numeramento de 1527-1532, Penélope, Lisboa.

Daveau, S.; Ribeiro, O. (1986) - Conhecimento actual da História da Geografia em Portugal, em História e Desenvolvimento da Ciência em Portugal, Academia das Ciências de Lisboa, Lisboa, II: 1041-1060.

Dias, J. J. A. (1999) - Gentes e Espaços. Edição crítica do Numeramento de 1527-1532. Dicionário Corográfico do Portugal Quinhentista, Comarca de Entre Douro e Minho; Comarca de Entre Tejo e Guadiana, Patrimonia Histórica, Cascais, 204 p.; 226 p.

Ferreira, A. et al. (1956-57) - O mais antigo mapa de Portugal, Boletim do Centro de Estudos Geográficos, Coimbra, 12-13: 3-66; 14-15: 10-43.

FIne, O. (1532) - Protomathesis, Paris.

Freire, A. B. (1905-1909) - Povoação de Entre Douro e Minho no XVI século; Id. Entre Tejo e Guadiana; Id. Estremadura; Id. Trás-os-Montes, Archivo Historico Portuguez, Lisboa, III, 1905; IV, 1906; VI, 1908; VII, 1909.

Galego, J.; Daveau, S. (1986) - O Numeramento de 1527-1532. Tratamento Cartográfico, Memórias do Centro de Estudos Geográficos, 9, Lisboa, 121 p.

García Mercadal, J. (1959) - Juan Bautista Labaña, em Viajes de Extranjeros por España y Portugal, II, Siglo XVII, Aguilar, Madrid: 157-321.

Hernando, A. (1996) - La Imagen de un Pais. Juan Bautista Labaña y su mapa de Aragon (1610-1620), Institución Fernando el Católico, Zaragossa.

Índice Hidrográfico. Classificação Decimal dos Cursos de Água de Portugal (1981) - Direcção-Geral dos Recursos e Aproveitamentos Hídricos, Lisboa, 2 vols.

Kaufman, K. (1988) - An Early Portuguese Geographical Index. The Longitudo et Latitude Lusitaniae and its relations to sixteenth mapping techniques, University of Wisconsin-Madison, 138 p. pol. 
Labaña, D. J. B. (1895) - Itinerario del Reino de Aragón, Establecimento Tipográfico del Hospicio Provincial, Zaragoza.

LEÃo, D. N. (1785) - Descripção do Reino de Portugal, 2. ${ }^{a}$ ed., Simão Thaddeo Ferreira, Lisboa (nova edição anotada, no prelo).

Magalhães, J. R. (1993) - No Alvorecer da Modernidade, em História de Portugal. (Mattoso, José, dir.), III, Círculo de Leitores, Lisboa, 608 p.

Marcel, G. (1899) - Les origines de la carte d'Espagne, Revue Hispanique, 6, Paris.

PMC (1960) - Cortesão, A.; Mota, A. T. da, Portugaliae Monumenta Cartographica, Lisboa, 6 volumes (2. ${ }^{\text {a }}$ edição: 1987 , com adenda).

Resende, A. (1593) - De Antiquitatibus Lusitaniae, Évora.

Resende, A (1996) - As Antiguidades da Lusitânia (Introdução, tradução e comentário de R. M. Rosado Fernandes), Fundação Calouste Gulbenkian, Lisboa, 660 p.

Tesouros da Cartografia Portuguesa (1997) - Comissão Nacional para a Comemoração dos Descobrimentos Portugueses; Edições INAPA, Lisboa, 159 p.

Vasconcelos, J. A. A. F. (1930) - O primeiro mapa impresso de Portugal e notas genealógicas sobre a família Seco, Arqueologia e História, 8: 27-33.

Vasconcelos, L. M. (1608) - Do Sítio de Lisboa, Lisboa. 